Modern Trends in Immunology, I

Edited by Prof. Robert Cruickshank. Pp. vii +263. (London: Butterworth and Co. (Publishers), Ltd., 1963.) $65 s$.

T

HE rapid developments in immunology to-day undoubtedly call for a 'modern trend' series to supplement the classical text-book treatment of the subject. The horizons of immunology are expanding all the more quickly because of the removal of barriers between different disciplines and the exchange of techniques.

This book is indeed a good start to a series of such modern trends. Although much of the basic knowledge is reviewed, for completeness, the modern views are put into perspective and recent technical developments are well covered. The ehapters on immunity have nothing new to add when dealing with natural or acquired bacterial immunity and it is surprising to see so much space allotted to such text-book information. The chapters on acquired viral and protozoal immunity, however, bring the subject up to date. The chapter on immunization "follows a course more or less as empirical as the subject itself" (to quote the author), and it is unfortunate that the reporting of the part played by maternal antibody is not up to date. In this chapter there is much overlap with that on acquired bacterial immunity. Hypersensitivity is well presented and, as the author says, the different disciplines now engaged in this subject may well result in the resolution of many of the problems in the next few years. The chapters on auto-immunity and transplantation immunology are most informative and do much to bring the book into the modern trend. Here again it is noteworthy that the authors comment that "the fusion of transplantation with other immunological disciplines also involves a complementary process".

This book is most useful to the post-graduate student and $w \theta$ hope it is the first of an interesting and informative series.

F. T. PERKINS

\section{Electrical Machinery and Control}

By Prof. Irving L. Kosow. (Prentice-Hall Series in Engineering Technology.) Pp. $x x+707$. (Englewood Cliffs, N.J., and London: Prentice-Hall, Inc., 1964.) $94 s$.

NE of the major difficulties that impose unnecessary restrictions for the control engineer designing a complex system is that the specialist designers of the components that go to make up the system are motivated by different criteria. Thus, the electrical machine designer is concerned with iron and copper losses and with stray load losses. While these are the keystones of good design for large power machines when used independently, they are of secondary importance to such factors as control. lability, torque to inertia ratio and power gain when used as a component part of a control mechanism.

It is therefore with great expectation that one approaches a now work combining both control and machinery. The connexion is, however, never made; control is represented by a final short chapter on servomechanisms so elementary and trivial as to be useless. Not once in the whole 700 pages are the dynamic characteristics of machines mentioned. The steady-state approach is used throughout and so is of little use to the control engineer. 'The addition of the term 'Control' to the title of the book is thus misleading.

As a book on machine principles it is also very doubtful if it will arouse much interest. It is written in an elementary manner with no attempt at analysis and a lack of modern fundamental unifying concepts. As an example one could quote the treatmont of the force on a conductor carrying current in a magnetic field. The simple law is quoted but there is no discussion on the physical implications. There is no treatment of current embedded in slots in iron and the distribution of forces on the iron, and little evidence for the student that in modern machines the field around a conductor is negligible and that the tooth forces produce the drive.

It is also extremely naive in its approach. After stating that synchronous induction motors are only made in smaller sizes, it says "Because of the salient pole rotor" the motor pulls into synchronism quite easily ....". This is not true; it is the difficulty of the synchronizing phenomenon (which is a transient dynamic problem and therefore ignored) which prevents large-scale machines of this type from being constructed.

Each chapter concludes with a number of problems and the answers given separately. A set of trigonometry tablos is provided as an appendix. JOHN C. WEST

\section{Beryllium Oxide}

Edited by R. Smith and J. P. Howe. (Proceedings of the First International Conference on Beryllium Oxide, Sydney, Australia, October 21-25, 1963.) (Reprinted from Journal of Nuclear Materials, 14, 1964.) Pp. 498. (Amsterdam: North-Holland Publishing Company, 1964.) $200 s$.

THE first International Conference on Beryllium Oxide, attended by scientists from six countries, was held at Sydney in October 1963. The conference was sponsored and organized by the Australian Atomic Energy Commission to review and discuss recent advances in knowledge of the behaviour of beryllium oxide, particularly from the point of view of its possible use in nuclear reactor systems, as a moderator material.

The present volume, which is reprinted from the Journal of Nuclear Materials, is a collection of the fifty-five papers presented at that Conference, together with an account of the discussion which they provided. The papers are divided into seven sections. These deal with: (i) utilization of beryllium oxide in nuclear reactors; (ii) radiation effects in beryllium oxide; (iii) structure and physical properties of beryllium oxide; (iv) sinterability and sintering of beryllium oxide powders; (v) fab. rication and mechanical properties of beryllium oxide; (vi) corrosion of beryllium oxide by water vapour; (vii) beryllium oxide-based dispersion fuels.

The book is attractively produced.

\section{F. LAPPERT}

\section{European Brewery Convention}

Report of the Barley Committee: Trials, 1963. Pp. 184. (London: The Institute of Brewing, 1965.) $15 s$.

7 HIS consists very largely of tabulated results of growth and malting trials of about twelve comparatively new hybrid barley varieties in fifteen Western European countries. The data, mostly arranged country by country but with a broad introductory survey, cover a much wider range than might be anticipated. Thus, they include summaries of trial lay-out, field observations, meteorological conditions as well as the crops themselves and their analytical examination. The objects behind this massive effort are not specifically or solely concerned with those qualities, such as disease resistance, yield, earliness in ripening and production of straw, which might first come to mind. These considerations are all economically important but are in the present context secondary to the main one of malting quality It is clearly unlikely that any one variety will be equally desirable under a wide range of climatic and agricultural conditions. The continuing experience afforded by these trials, nevertheless, must be generally valuable, not least in respect of the economic conditions brought about by the European Common Market. The scientific value of this Report, however, encompasses more than the results themselves or the clear way they are presented; it presents what is probably a unique picture of the inevitable complexity involved in selecting improved varieties of even a single crop when many slight or scarcely appreciated variables may be brought into play.
A. H. Cook 